\title{
REFORMULASI KEBIJAKAN FORM A5-KOMISI PEMILIHAN UMUM SEBAGAI UPAYA PERLINDUNGAN HAK POLITIK
}

\author{
Ninik Zakiyah, Lita Tyesta Addy Listya Wardhani \\ Magister Ilmu Hukum, Universitas Diponegoro, Semarang, Indonesia \\ ninik.zakiyah@gmail.com
}

\begin{abstract}
Abstrak
Pemilihan umum sebagai momen paling penting dalam menjalankan demokrasi, karena demokrasi bagi bangsa Indonesia merupakan tatanan kenegaraan yang juga sesuai dengan martabat manusia yang menghormati dan menjamin pemenuhan Hak Asasi Manusia (HAM). Memberikan hak suara pada setiap pemilu dapat dilakukan di Tempat Pemungutan Suara (TPS) luar daerah asal dengan menggunakan form A5-Komisi Pemilihan Umum (KPU), yang tentu dalam mengurusnya harus sesuai prosedur. Metode penelitian ini menggunakan metode yuridis-normatif dengan pendekatan undang-undang, pendekatan konseptual, dan pendekatan kasus. Sumber data didapat dari sumber data sekunder dari bahan hukum primer, bahan sekunder, dan bahan hukum tersier baik dalam bentuk jurnal, buku-buku, undang-undang, dan sumber terkait lainnya. Secara prosedural Peraturan Komisi Pemilihan Umum (PKPU) Nomor 3 tahun 2019 telah mengatur secara jelas, namun dalam pelaksanaanya menemui kendala seperti prosedur yang dirasa terlalu ribet dan beberapa pihak penyelenggara yang kurang paham prosedurnya sehingga ada calon pemilih tidak bisa mendapatkan form A5-KPU akibatnya kehilangan hak pilihnya. Dinamisnya peristiwa masyarakat mengharuskan relevansi sebuah peraturan harus terus dipantau agar mampu memenuhi kebutuhan setiap warga Negara, untuk itu perlu adanya formulasi ulang terkait kebijakan tersebut agar mampu mengakomodir secara komprehensif.
\end{abstract}

Kata kunci: reformulasi kebijakan; form A5-Komisi Pemilihan Umum; perlindungan hak politik

\section{Abstract}

Election as the most important moment in carrying out democracy, because democracy for the Indonesian people is a state order that is also per human dignity that respects and guarantees the fulfillment of Human Rights (HAM). Giving voting rights in each election can be done at the Polling Station (TPS) outside the area of origin by using the A5-Election Commission (KPU) form, which of course in handling it must be according to the procedure. This research method uses a juridical-normative method with a law approach, conceptual approach, and case approach. Sources of data obtained from secondary data sources from primary legal materials, secondary materials, 
and tertiary legal materials in the form of journals, books, laws, and other related sources. Procedurally, the Election Commission Regulation (PKPU) No. 3 of 2019 has regulated it, but in its implementation encountered obstacles such as procedures that were considered too complicated and some organizers who did not understand the procedures so that there were potential voters who could not get the A5-KPU form as a result of losing his vote. The dynamics of community events require that the relevance of a regulation must be continuously monitored to be able to meet the needs of every citizen, for this reason, it is necessary to reformulate the policy to be able to accommodate comprehensively.

Keywords: policy reformulation; Form A5-Election commission; protection of political rights

\section{Pendahuluan}

Sistem pemerintahan sangat dibutuhkan dalam mengatur suatu Negara. Salah satu bentuk sistem pemerintahan tersebut adalah demokrasi. Demokrasi adalah suatu sistem politik yang sistem pemerintahannya berasal dari rakyat, ${ }^{1}$ sebagaimana secara etimologis istilah "Demokrasi" berasal dari dua kata yaitu demos dan cratos/cratein. Demos bermakna rakyat, dan cratos berarti pemerintahan. ${ }^{2}$ Pemahaman dan perkembangan demokrasi di setiap Negara tidaklah sama, sehingga menurut Mahfud MD., demokrasi bersifat relatif. Perkembangan demokrasi di suatu Negara menunjukan tidak ada suatu negara yang betul-betul demokratis dan tidak ada suatu negara yang sepenuhnya otoriter. $^{3}$

Undang-Undang Dasar (UUD) 1945 secara tegas menyatakan bahwa pemerintahan demokrasi berasaskan kedaulatan rakyat, sebagaimana terdapat dalam pembukaan UUD 1945 alinea keempat, Pasal 1 ayat (2) UUD 1945 hasil amandemen ketiga. Di dalam perkembangannya, Indonesia telah menerapkan beberapa sistem demokrasi, namun yang masih dipertahankan hingga sekarang yang kita kenal yaitu Demokrasi Pancasila. UUD 1945 menganut pelaksanaan demokrasi berdasarkan kedaulatan rakyat tidak dilaksanakan oleh rakyat secara langsung melainkan melalui lembaga-lembaga perwakilan rakyat

${ }^{1}$ Andi Yuliani, Hak Konstitusional Warga Negara, Artikel Hukum Tata Negara dan Peraturan Perundang-undangan, diakses dari http://ditjenpp.kemenkumham.go.id/htn-danpuu/2971-hak-konstitusional-warga-negara.html Pada 22 September 2019 Pukul 14.00 WIB.

${ }^{2}$ Bobi Aswandi dan Kholis Roisah, Negara Hukum dan Demokrasi Pancasila dalam Kaitannnya dengan Hak Asasi Manusia (HAM), Jurnal Pembangunan Hukum Indonesia, Volume 1, Nomor 1, 2019, 128-145, hlm. 136.

${ }^{3}$ Moh. Mahfud MD, Politik Hukum di Indonesia, Rajawali Pers, Jakarta, 2017, hlm. 23. 
seperti Dewan Perwakilan Rakyat (DPR) dan Majelis Permusyawaratan Rakyat (MPR), dan demokrasi dalam pandangan hidup atau demokrasi sebagai falsafah bangsa. ${ }^{4}$ Sehingga dapat kita ketahui bahwa sistem demokrasi dalam penyelenggaraan negara harus didasarkan pada partisipasi dan kepentingan rakyat.

Kegiatan bernegara di Indonesia dan pemilu dengan berbagai macam bentuknya sebagai salah satu manifestasi dari Demokrasi Pancasila, begitu penjelasan Padmo Wahyono terkait Demokrasi Pancasila. ${ }^{5}$ Demokrasi Pancasila sebagai indirect demokrasi mensyaratkan adanya Pemilu sebagai sarana dalam melaksanakan kedaulatan rakyat. Pemilu sendiri merupakan salah satu cara untuk menjamin tersalurkannya suara rakyat secara langsung, umum, bebas, rahasia, jujur, dan adil. Selain itu dalam pelaksanaan demokrasi pancasila diperlukan wakil-wakil rakyat yang dipilih melalui Pemilu yang nantinya dapat mewakili suara rakyat di lembaga-lembaga perwakilan rakyat. Dalam proses Pemilu ini sangat berkaitan dengan salah satu hak yang dilindungi oleh Hak Asasi Manusia, yaitu hak untuk memilih dan dipilih dalam berpolitik atau hak politik. Undang-Undang Nomor 39 Tahun 1999 tentang Hak Asasi Manusia, mendefinisikan:

“...Hak Asasi Manusia adalah seperangkat hak yang melekat pada hakikat dan keberadaan manusia sebagai makhluk Tuhan Yang Maha Esa dan merupakan anugerah-Nya yang wajib dihormati, dijunjung tinggi, dan dilindungi oleh negara hukum, pemerintahan, dan setiap orang demi kehormatan serta perlindungan harkat dan martabat manusia..."

Dalam Undang-Undang tersebut mengatur hak berpolitik yang terdapat dalam Pasal 23 ayat (1), Pasal 24 ayat (1) dan ayat (2). Pengaturan tersebut sejalan dengan Pasal 28 UUD 1945 dan Pasal 28 E ayat (3) UUD 1945 amandemen kedua. Aturan tersebut merupakan aktualisasi dari hak untuk memilih, berserikat dan berkumpul dalam partai politik atau organisasi lain sebagai perwujudan hak berpolitik yang dimiliki oleh setiap orang. Prinsip pengakuan dan perlindungan terhadap hak-hak asasi manusia, merupakan bagian dari prinsip perlindungan hukum. Hak Berpolitik yang merupakan salah satu hak asasi manusia menganut asas demokrasi yang utamanya adalah hak turut serta dalam pemerintahan. ${ }^{6}$ Hak untuk dipilih sebagaimana dalam Pasal

\footnotetext{
${ }^{4}$ Cora Elly Noviati, Demokrasi dan Sistem Pemerintahan, Jurnal Konstitusi, Volume 10, Nomor 2, 2013, hlm. 337.

${ }^{5}$ Bobi Aswandi dan Kholis Roisah, Loc Cit.,

${ }^{6}$ Andi Yuliani, Hak Politik Warga Negara (Sebuah Perbandingan Konstitusi), Artikel Hukum Tata Negara dan Peraturan Perundang-Undangan, diakses dari http://ditjenpp.kemenkumham.go.id/htn-dan-puu/2941-hak-politik-warga-negara-sebuahperbandingan-konstitusi.html pada 23 September 2019 Pukul 15.32 WIB
} 
28 C ayat (2), Pasal 28 D ayat (3). Mengenai hak turut serta dalam pemerintahan disebutkan dalam Pasal 43 Undang-Undang Nomor 39 Tahun 1999 tentang Hak Asasi Manusia.

Berdasarkan penjelasan diatas dapat kita ketahui bahwa di dalam masyarakat yang demokratis, hak-hak sipil dan kebebasan dihormati dan dijunjung tinggi, kebutuhan akan kebebasan individual harus dipenuhi. ${ }^{7}$ Hak-hak sipil (individu) ini merupakan klasifikasi hak-hak sipil dan politik yang dilindungi oleh Hak Asasi Manusia. Negara diminta untuk melindungi dan memfasilitasi agar semua individu ikut berpartisipasi dalam kehidupan masyarakat Negara dalam hal ini adalah hak berpolitik ${ }^{8}$.

Indonesia sebagai Negara demokrasi memberlakukan sistem Pemilihan Umum (Pemilu) setiap lima tahun sekali sebagai wujud demokrasi, mulai dari pemilihan tingkat kabupaten sampai tingkat pusat. Baik berupa pemilihan legislatif, pemilihan gubernur, dan pemilihan presiden. Pemilu secara langsung sebagai momen paling penting dalam menjalankan demokrasi, karena demokrasi bagi bangsa Indonesia merupakan tatanan kenegaraan yang sesuai dengan martabat manusia yaitu menghormati dan menjamin pemenuhan Hak Asasi Manusia (HAM). Pro kontra kontestasi politik rutinan lima tahun sekali menjadi penting bagi setiap warga untuk menjada stabilitas keutuhan Negara Kesatuan Republik Indonesia (NKRI), ${ }^{9}$ dan kualitas pemilu menjadi salah satu indikator kesuksesan demokrasi. ${ }^{10}$

Pelaksanaan pemilu masih menyisakan kekecewaan di masyarakat, terlebih pada pemilih pindah Tempat Pemungutan Suara (TPS) yang dipengaruhi banyak faktor seperti bekerja, keperluan study, ataupun hal lainnya. Hadirnya pemilih dapat dipengaruhi oleh kesadarannya memilih, tapi ada juga karena politik uang. ${ }^{11}$ Pemerintah memang telah mengatur prosedur memilih pindah TPS agar masyarakat yang sedang berada luar daerah asal tetap bisa memberikan hak suaranya di pemilihan umum melalui form A5-Komisi Pemilihan Umum (A5-KPU) sebagaimana diatur dalam Peraturan Komisi Pemilihan Umum (PKPU) Nomor 3 tahun 2019 tentang Pemungutan dan Penghitungan Suara dalam Pemilihan Umum.

\footnotetext{
${ }^{7}$ Ellya Rosana, Loc Cit

${ }^{8}$ Boer Mauna, Hukum Internasional, Pengertian, Peranan dan Fungsi dalam Era Dinamika Global, Bandung: Alumni, 2003, hlm. 595

${ }^{9}$ R. Siti Zuhro, Demokrasi dan Pemilu Presiden 2019, Jurnal Penelitian Politik LIPI dalam Dinamika Sosial Politik Menjelang Pemilu Serentak 2019, Vol. 16, No. 1, 2019, hlm. 6970

${ }^{10}$ Lati Praja Delmana, Aidinil Zetra, dan Alfan Miko, Konstruksi Indikator dan Formula Penilaian Kualitas Pemilihan Umum di Indonesia, JPPUMA: Jurnal Ilmu Pemerintahan dan Sosial Politik UMA, Vol. 7, No 1, 2019, hlm. 61.

${ }^{11}$ Agus Machfud Fauzi, Perilaku Pemilih Menjelang Pemilu 2019, Journal of Islamic Civilization, Vol. 1, No. 1, 2019, hlm. 41.
} 
Mengurus form A5-KPU masih banyak dijumpai kesulitan hingga mengakibatkan hilangnya hak pilih. Kasus yang dimuat dalam media online idntimes.com memberikan sebuah fakta bahwa ada seseorang asal Sumedang, Jawa Barat, yang sedang bekerja di Jakarta Barat, dia gagal mendapatkan form A5-KPU dikarenakan ia libur kerja di waktu tanggal pemilu, ia dapat memiliki form A5-KPU apabila jadwal kerjanya masuk di waktu tanggal pemilu. Seperti seseorang yang berprofesi sebagai pelayar, ia berhasil mendapatkan form A5-KPU karena pada 17 April 2019 ia melaksanakan pelatihan di wilayah Palmerah, lalu bagi yang tangal 17 April 2019 sedang libur bekerja, mereka diminta untuk mencoblos di daerah asal. ${ }^{12}$ Keluhan datang silih berganti dari masyarakat karena sulitnya mengurus form A5-KPU. Libur bekerja atau study yang hanya sehari sedangkan biaya kepulangan yang menghabiskan ongkos banyak terlebih di luar pulau dirasa tidak cukup untuk kembali ke daerah asalnya.

Penelitian Ayon Diniyanto tentang Politik Hukum Regulasi Pemilihan Umum di Indonesia: Problem dan Tantangannya, dalam penelitian tersebut mengemukakan bahwa payung hukum pelaksanaan pemilu yaitu UndangUndang Nomor 7 tahun 2017 tentang pemilihan umum menggunakan criteria kebijakan hukum yang dikeluarkan, latar belakang kebijakan hukum, dan penegakan hukum dari kebijakan yang dikeluarkan. Kemudian juga membahas isu permasalahan dan tantangan terkait presidential threshold, parliamentary threshold, sistem pemilu, daerah pemilihan magnitude, dan metode konversi suara. ${ }^{13}$ Selanjutnya Ester Eita Motoh dalam penelitiannya yang berjudul Kinerja Komisi Pemilihan Umum Minahasa Selatan dalam Pelaksanaan Pemillu Legislatif tahun 2014, dalam penelitian tersebut menyinggung soal tidak maksimalnya Daftar Pemilih Tetap (DPT) dimana masih ada beberapa calon pemilih yang telah memenuhi syarat namun tidak terdaftar kedalam DPT, hal ini dikarenakan faktor sumber daya manusia anggota penyelenggaranya sehingga berdampak pada kinerja Pemilu di Minahasa Selatan. ${ }^{14}$ Kemudian penelitian Nopi Amalia dan Andi Mulyadi menejlaskan bahwa formulis pindah memilih atau A5 menjadi strategi KPU untuk mengurangi angka golput. ${ }^{15}$ Berbeda dengan tulisan ini yang tidak hanya membahas soal DPT dan

12 Mahasiswa Tak Bisa Mengurus Formulir A5, Kenapa? https://www.idntimes.com/news/indonesia/sunariyah/mahasiswa-tak-bisa-mengurusformulir-a5-kenapa, diakses pada 21 September 2019 Pukul 22.01 WIB

${ }^{13}$ Ayon Diniyanto, Politik Hukum Regulasi Pemilihan Umum di Indonesia: Problem dan Tantangannya, Jurnal Legislasi Indonesia, Vol. 16, No. 2, 2019, 160-172

14 Ester Meita Motoh, Kinerja Komisi Pemilihan Umum Minahasa Selatan dalam Pelaksanaan Pemilu Legislatif tahun 2014, Jurnal Politico, Volume 7, Nomor 3, 2018, 1-23.

${ }^{15}$ Nopi Amalia dan Andi Mulyadi, Strategi Komisi Pemilihan Umum dala Mengurangi Angka Golput Pada Pemilihan Presiden dan Wakil Presiden, JOPPAS: Journal of Public Policy and Administration Silampari, 1 (1), 2019, hlm. 1. 
payung hukum pemilu UU Nomor 7 tahun 2017 saja namun juga membahas problematika mendapatkan form A5-KPU khususunya bagi pemilih yang sedang tidak berada di daerah asal untuk tetap bisa memberikan hak pilihnya.

\section{Permasalahan}

Berdasarkan uraian di atas berikut rumusan masalah: 1). Bagaimana prosedur mengurus form A5-Komisi Pemilihan Umum? 2). Bagaimana reformulasi kebijakan prosedur mengurus form A5-Komisi Pemilihan Umum untuk melindungi hak politik?

\section{Metode Penelitian}

Metode penelitian ini menggunakan metode penelitian yuridis-normatif. Penelitian ini mendiskripsikan dan menganalisis prosedur mendapatkan form A5-KPU sebagai alternatif cara memilih di luar daerah asal untuk melindungi Hak Politik setiap warga Negara, namun ternyata masih dijumpai kendala dalam mengurusnya. Menunjang penelitian yuridis-normatif ini digunakan pula pendekatan kasus (case approach), pendekatan undang-undang (statute approach) dan pendekatan konseptual (conceptual approach). ${ }^{16}$ Pendekatan kasus dilakukan dengan cara menelaah kasus hasil wawancara dengan narasumber terkait secara satu arah yaitu terbatas pada satu narasumber dan kasus yang telah diberitakan dalam banyak media yang credible, pendekatan undang-undang dilakukan dengan menelaah undang-undang dan regulasi yang terkait dengan tema penelitian. Pendekatan konseptual dilakukan dengan mengkaji dan menyusun konsep demokrasi dan pemilu serta form A5-KPU.

Data yang dibutuhkan dalam penelitian ini adalah data sekunder, baik dengan bentuk bahan hukum primer, bahan hukum sekunder, dan bahan hukum tersier dalam bentuk undang-undang, jurnal, buku, dan sumber terkait lainnya. Bahan-bahan hukum diperoleh dengan studi kepustakaan (library research). Metode analisis penelitian menggunakan yuridis kualitatif, yaitu bahan hukum tidak dianalisis dengan rumus statistik melainkan dengan pendekatan penafsiran hukum dan konstruksi hukum dengan cara berfikir deduktif. ${ }^{17}$

\section{Pembahasan}

\section{Prosedur Mengurus Form A5-Komisi Pemilihan Umum}

${ }^{16}$ Peter Mahmud Marzuki, Penelitian Hukum, (edisi revisi), Prenadamedia Group, Jakarta, 2015, hlm. 133-136.

${ }^{17}$ Soetandyo Wignjosoebroto, Hukum: Konsep dan Metode, Setara Press, Malang, 2013, hlm. 52. 
Diperlukan pengaturan yang jelas dan pemahaman secara holistic terhadap kondisi masyarakat Indonesia yang majemuk dan kompleks. Pemilu menjadi sarana masyarakat berekspresi dan menempatkan hak dipilih dan memilihnya. tidak terkecuali Komisi Pemilihan Umum (KPU) sebagai penyelenggara pemilu. Perlu pendataan yang akurat dan faktual terhadap data pemilih meskipun masyarakat Indonesia dengan kondisi yang begitu kompleks, namun KPU tentu mempunyai siasat dengan memberikan kebijakan adanya sistem pendataan Daftar Pemillih Tetap (DPT), dan atau Daftar Pemilih Tambahan (DPTb).

DPT adalah daftar pemilih KTP-el yang terdaftar dalam Daftar Pemilih Sementara (DPS) hasil Pemutakhiran yang telah diperbaiki oleh PPS ${ }^{18}$ dan ditetapkan oleh $\mathrm{KPU}^{19} / \mathrm{KIP}^{20}$ Kabupaten/Kota. ${ }^{21}$ Selain sebagai acuan dalam alur pemungutan suara oleh KPPS (Kelompok Penyelenggara Pemungutan Suara $)^{22}$, DPT juga berfungsi sebagai pendataan individual, serta mendeteksi siapa saja yang telah berhak memilih. Data DPT ini selalu di verifikasi secara berkala, sehingga data pertumbuhan setiap warga akan terlihat, seperti yang telah meninggal akan dihapus atau di TMS-kan (Tidak Memenuhi Syarat). ${ }^{23}$

Mengingat kompleksitas masyarakat, jika merujuk pada masing-masing keperluan individu tidak akan ada habisnya, namun tetap ada ketentuan lain

${ }^{18}$ Panitia Pemungutan Suara (PPS) adalah panitian yang dibentuk oleh KPU/KIP Kabupaten/Kota untuk melaksanakan pemilu di tingkat kelurahan/desa atau nama lain, lihat dalam Komisi Pemilihan Umum Republik Indonesia, Panduan Pelaksanaan Pemungutan dan Penghitungan Suara di TPS Pemilu Tahun 2019, hlm. v

19 Komisi Pemilihan Umum yang selanjutnya disingkat KPU adalah lembaga penyelenggara pemilu yang bersifat nasional, tetap, dan mandiri dalam pelaksanaan pemilu, lihat dalam Undang-Undang Nomor 7 tahun 2017 tentang Pemilihan Umum, Buku Kesatu Ketentuan Umum, Bab I Pengertian Istilah, Pasal 1, Ayat 8,

${ }^{20}$ Komisi Independen Pemilihan selanjutnya disingka KIP adalah KIP Aceh dan KIP Kabupaten/Kota yang merupakan bagian dari Komisi Pemilihan Umum (KPU) yang diberi wewenang oleh Undang-Undang ini untuk menyelenggarakan Pemilihan Umum Presiden/Wakil Presiden, anggota Dewan Perwakilan Rakyat, anggota Dewan Perwakilan Daerah, anggota DPRA/DPRK, Pemilihan Gubernur/Wakil Gubernur, bupati/wakil bupati, dan walikota/wakil walikota, lihat dalam Undang-Undang Nomor 11 Tahun 2006, Bab 1 Ketentuan Umum, Pasal 1, Ayat 12, lihat juga Qanun Aceh Nomor 6 Tahun 2016 tentang Penyelenggaran Pemilihan Umum dan Pemilihan di Aceh, Bab 1 Ketentuan Umum, Pasal 1, Ayat 17.

${ }^{21}$ Komisi Pemilihan Umum Republik Indonesia, Panduan Pelaksanaan Pemungutan dan Penghitungan Suara di TPS Pemilu Tahun 2019, hlm. v

${ }^{22}$ Kelompok Penyelenggara Pemungutan Suara (KPPS) adalah kelompok yang dibentuk oleh PPS atas nama KPU/KIP kab/kota untuk melaksanakan pemungutan dan peng- hitungan suara di TPS, lihat Panduan Pelaksanaan Pemungutan dan Penghitungan Suara di TPS Pemilu Tahun 2019, hlm. v

${ }^{23} \mathrm{Pada}$ jadwal pemilihan umum yang terbaru dalam pemlihan lembaga legislatif dan pemilihan presiden serta wakil presiden, terlihat verifikasi berkas secara berkala, dapat dilihat di PKPU Nomor 7 tahun 2019 tentang Perubahan Ke Tiga atas PKPU Nomor 7 tahun 2019 tentang Tahapan, Program, dan Jadwal Penyelenggaraan Pemilihan Umum tahun 2019. 
yang pasti dibutuhkan. Dalam hal ini KPU memberikan ruang adanya DPTb, yaitu daftar pemilik KTP-el yang terdaftar dalam DPT karena keadaan tertentu tidak dapat memberikan suara di TPS tempat Pemilih yang bersangkutan terdaftar dalam DPT, kemudian dapat memberikan suara di TPS lain. ${ }^{24}$ Dalam klausa keadaan "tertentu" KPU juga memfasilitasi adanya formulir model A5KPU, formulir ini adalah surat pemberitahuan pemilih tambahan, berikut contohnya dapat dilihat di bawah:

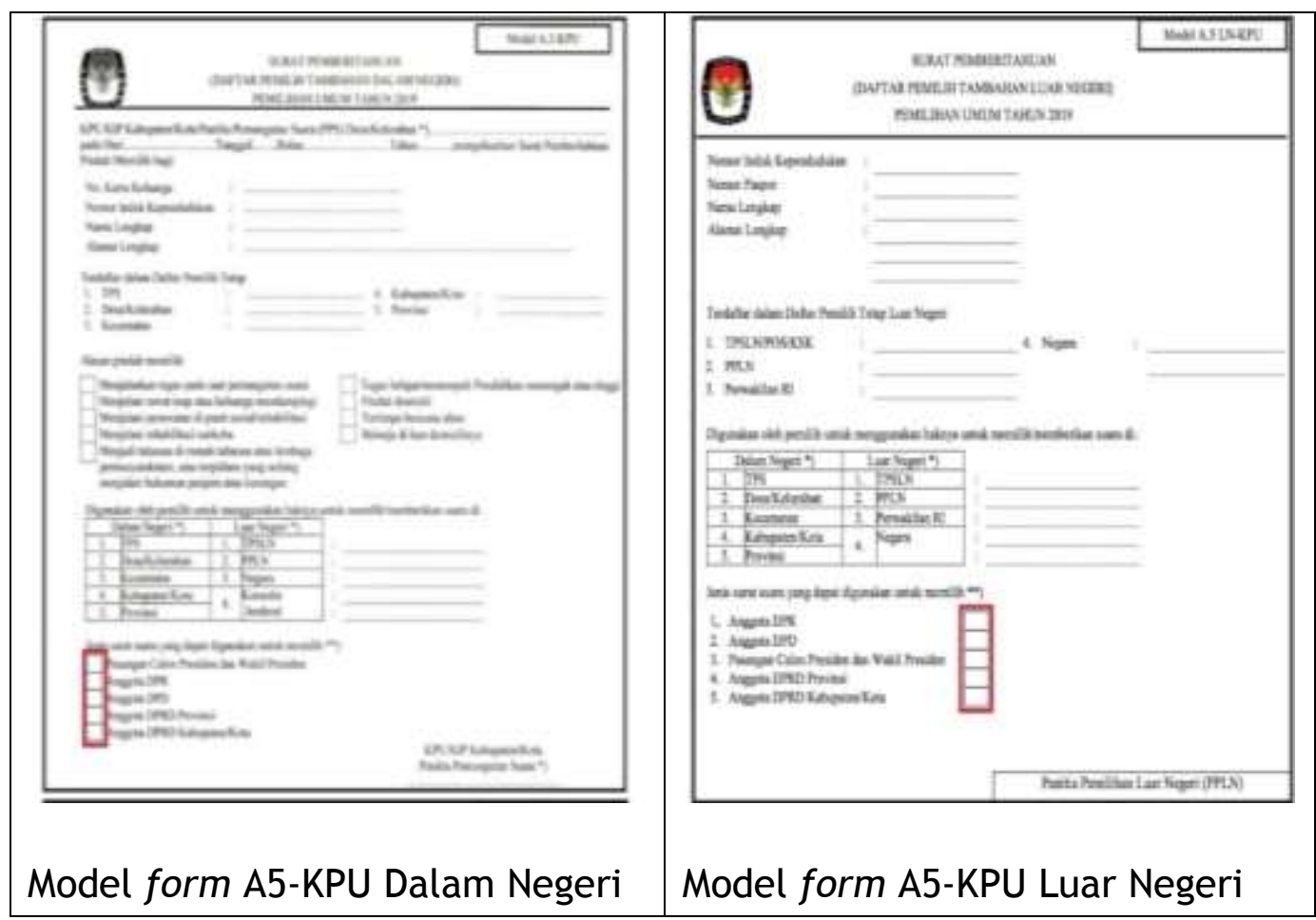

Prosedur mengurus form A5-KPU disebutkan dalam Peraturan Komisi Pemilihan Umum (PKPU) Nomor 3 Tahun 2019 Pasal 8 ayat 5 sampai 15. ${ }^{25}$ Pemilih yang akan memberikan hak suaranya di TPS lain atau TPSLN harus melapor dulu ke PPS asal guna memperoleh form A5-KPU dengan menunjukkan KTP-el atau identitas lain (surat keterangan rekaman KTP sementara), dan atau salinan bukti telah terdaftar di DPT, dan melaporkan ke PPS atau PPLN tujuan dengan tenggat waktu paling lambat 30 (tiga puluh) hari sebelum hari pemungutan suara (Pasal 5).

Ketika pemilih tidak dapat mengurus di PPS asal (sebagaimana Pasal 5) maka pemilih boleh mendapatkan form A5-KPU ke KPU/KIP Kabupaten/Kota asal (Pasal 6), namun jika hal tersebut tidak bisa dilakukan boleh

${ }^{24}$ Komisi Pemilihan Umum Republik Indonesia, Ibid.,

${ }^{25}$ Lihat Peraturan Komisi Pemilihan Umum (PKPU) Nomor. 3 Tahun 2019 Tentang Pemungutan dan Penghitungan Suara dalam Pemilihan Umum 
mendapatkan form A5-KPU di KPU/KIP Kabupaten/Kota daerah tujuan dengan waktu paling lambat 30 (tiga puluh) hari sebelum masa pemungutan suara (Pasal 7). Setelah dilakukan pengecekan nama pemilih yang memohon form A5-KPU ada di DPT maka PPS, KPU/KIP Kabupaten/Kota daerah asal atau tujuan menghapus nama tersebut di DPT daerah asal dan menerbitkan form A5-KPU (Pasal 8 sampai 9).

KPU/KIP Kabupaten/Kota asal dengan daerah tujuan berkoordinasi atas laporan permohonan form A5-KPU dari pemilih yang bersangkutan, melalui KPU untuk menghapus nama tersebut dari DPT daerah asal, kemudian PPS daerah tujuan menerima laporan tersebut selanjutnya nama tersebut dicatatkan dalam DPTb dan diberi nomor urut. Apabila yang bersangkutan tidak melapor ke PPS tujuan tetap dapat memberikan hak suaranya dengan menunjukkan form A5-KPU dan KTP-el atau identitas lain sebagaimana disebutkan dalam peraturan tersebut, adapun waktu pemberian hak suara di TPS mulai pukul 07.00 sampai 13.00 waktu setempat (Pasal 10 sampai 15).

\section{Reformulasi Kebijakan Mengurus Form A5-Komisi Pemilihan Umum Sebagai Upaya Perlindungan Hak Politik}

Pemilih yang boleh memberikan suaranya di TPS harus memenuhi kriteria, ini berdasarkan PKPU Nomor 3 tentang Pemungutan dan Penghitungan Suara dalam Pemilihan Umum meliputi:

a) Pemilik KTP-el yang terdaftar pada DPT di TPS bersangkutan. ${ }^{26}$

b) Pemilik KTP-el yang terdaftar pada DPTb. ${ }^{27}$

c) Pemilik KTP-el yang tidak terdaftar pada DPT dan DPTb

d) dan penduduk yang telah memiliki hak pilih. ${ }^{28}$

Merujuk pasal tersebut, salah satu syarat boleh mengikuti pemungutan suara di TPS adalah mempunyai KTP-el yang terdaftar dalam DPT di TPS bersangkutan atau DPTb.

${ }^{26}$ Pemilih yang terdapat di DPT memberikan suaranya di TPS tempat pemilih terdaftar di TPS dengan menunjukkan formulir Model C6-KPU dan KTP-el atau identitas lain, lihat pasal 7, ayat 1 dan 2, PKPU Nomor 3 tahun 2019 tentang Pemungutan Suara dan Penghitungan Suara dalam Pemilihan Umum.

${ }^{27}$ Pemilihan yang terdapat pada Daftar Pemilih Tambahan (DPTb) merupakan pemilih yang karena keadaan tertentu tidak dapat memberikan suara di TPS tempat asal pemlih terdaftar dalam DPT dan memberikan suara di TPS lain atau TPSLN, lihat PKPU Nomor 3 tahun 2019, Pasal 8, ayat 1.

${ }^{28}$ Lihat Pasal 348 ayat 1, Undang-Undang Nomor 7 tahun 2017 tentang Pemilihan Umum, lihat juga di Peraturan Komisi Pemilihan Umum Nomor 3 tahun 2019, Pasal 6. 
Dalam keadaan "tertentu" tersebut di atas, apabila seseorang berhalangan hadir di TPS daerah asal ia diperbolehkan menggunakan hak pilihnya di daerah ia tinggal, dengan catatan sebagaimana penjelasan di atas harus memenuhi unsur-unsur: mempunyai KTP-el dan tercatat dalam DPT. Setelah memenuhi unsur tersebut, baru bisa mengurus pindah memilih di TPS lain dengan form A5-KPU, yang kemudian tercatat di DPTb, dimana nama yang tercatat di DPT daerah asal dihapus. Sebagaiman disebutkan dalam PKPU No. 3 Tahun 2019 Pasal 8 ayat (5) sampai (15). Secara detail sudah di jelaskan terkait prosedur mengurus form A5-KPU pasal demi pasal. Dari mengurus form A5 yang awalnya di tempat asal, namun ketika tidak dimungkinkan boleh diurus di tempat ia tinggal bahkan dengan tenggat waktu yang dirasa cukup yaitu 30 (tiga puluh) hari.

Peraturan tersebut telah mengatur secara urut untuk memperoleh form A5-KPU, namun pada kenyataannya masih ada pihak-pihak yang susah mengurus form A5-KPU. Sebagaimana Noor Kholifah Hidayati ${ }^{29}$ paparkan bahwa ketika ia sedang menempuh studi di Jawa Timur, ia gagal memberikan hak suaranya karena begitu susah mengurus form A5-KPU, prosedurnya seperti diputar-putarkan, dan akhirnya sampai di TPS ia tidak bisa memberikan hak memilihnya, seperti terlihat ada pihak-pihak penyelenggara yang tidak paham mengurus form A5-KPU. la memilih memberikan hak pilihnya di tempat ia menempuh studi karena libur hanya sehari, terlebih hidup di lingkungan pondok pesantren, untuk kembali ke daerah asal yaitu Semarang membutuhkan waktu lama, sedangkan keperluan di pondok pesantren tidak bisa ditinggal begitu saja. ${ }^{30}$

Perlu adanya edukasi kepada penyelanggara pemilu sampai tingkat bawah yaitu KPPS, pihak yang secara langsung bersinggungan dengan masyarakat di TPS. Sebelumnya perlu juga pemberitahuan tentang adanya form A5-KPU secara menyeluruh sebagai syarat bisa pindah TPS, baik pindah TPS pindah daerah maupun pindah TPS lain. Masyarakat yang ingin melakukan pindah TPS juga sebaiknya memperhatikan peraturan tersebut, dan menanamkan kesadaran mengurus form A5-KPU untuk mengurusnya jauh-jauh hari terlebih ada tenggang waktu mengurusnya, jadi tidak secara mendadak mendekati waktu pemungutan suara baru mau mengurusnya.

${ }^{29}$ Mahasiswi Magister Ilmu Hukum Universitas Diponegoro angkatan 2019 konsentrasi Hukum Ekonomi dan Bisnis, asal Semarang, menempuh studi Strata Satu di salah satu Universitas di Jawa Timur 10.11 WIB

Hasil wawancara dengan Noor Kholifah Hidayati pada 25 November 2019 Pukul 
Pada kejadian sebagaiman di beritakan idntimes.com bahwa terdapat seseorang asal Sumedang, Jawa Barat, yang sedang bekerja di Jakarta Barat, dia gagal mendapatkan form A5 karena ternyata form A5 bisa diperoleh bagi mereka yang tidak sedang di daerah asal, dan sedang tidak libur bekerja atau studinya. Seperti seorang yang berprofesi sebagai pelayar, ia berhasil mendapatkan form A5 karena pada 17 April 2019 ia melaksanakan pelatihan di wilayah Pelmerah. Lalu bagi yang tangal 17 April 2019 sedang libur bekerja, mereka diminta untuk mencoblos di daerah asal. Begitu juga kasus yang penulis peroleh dari hasil wawancara dengan salah satu Mahasiswi Magister Ilmu Hukum Universitas Diponegoro angkatan 2019 di pembahasan sebelumnya, bahwa prosedur mengurus A5-KPU tak semulus dan semudah yang di uraikan dalam peraturan KPU.

Pada kejadian tersebut terlihat bahwa ada hak pilih dari seseorang yang hilang. Belum ada peraturan yang mengatur terkait penyebab gagalnya ia mendapatkan form A5-KPU yaitu libur atau tidaknya pekerjaan atau waktu study di saat tanggal pemilu berlangsung. Dapat kita ketahui bersama bahwa setiap adanya pemilu, pemerintah selalu menjadikan libur nasional, namun ada beberapa pihak baik dari perusahaan atau institusi lain yang meminta masuk atau bahkan tidak memungkinkan untuk diliburkan seperti pelayanan publik: rumah sakit, transportasi, sumber energi listrik dan hal terkait. Bagi pihak-pihak yang sedang dalam kondisi ini memungkinkan dapat memilih di TPS lain dengan adanya form A5-KPU dikarenakan tidak libur. Namun bagi perantau yang sedang libur, ini yang menjadi problematika diminta untuk memberikan hak suaranya di daerah asal, sedangkan jarak tempuh, serta biaya, dengan waktu memberikan hak pilihnya tidaklah sebanding. Secara prosedural, dalam PKPU Nomor 3 Tahun 2019 telah jelas mengaturnya, namun belum secara menyeluruh dapat mengakomodir kebutuhan masyarakat terlebih hak politiknya, untuk itu perlu adanya formulasi ulang dalam peraturan tersebut dalam memayungi kebutuhan hak politik setiap warga Negara. Perlu ditekankan pula terkait kesadaran masyarakat tentang mengurus form A5-KPU untuk mengurus jauh-jauh hari jika ingin melakukan pencoblosan pindah TPS dengan mempublikasikan lebih gencar lagi tentang adanya A5-KPU agar seluruh masyarakat mengetahuinya. 


\section{Penutup}

\section{Simpulan}

Hak untuk menggunakan suara dalam pemilihan umum termasuk dalam hak asasi yang diatur didalam UUD 1945 dan Undang-Undang Nomor 39 Tahun 1999 tentang Hak Asasi Manusia. Hak untuk memilih merupakan hak yang dimiliki oleh setiap warga negara, sebagaimana tertuang dalam Pasal 43 Ayat (1) UU No.39 Tahun 1999. Sebagai payung hukum pemilu bagi setiap warga Negara untuk memberikan hak pilihnya terdapat dalam Undang-Undang Nomor 7 Tahun 2017 tentang Pemilihan Umum. Prosedur memilih pindah TPS secara jelas tertuang dalam PKPU Nomor 3 tahun 2019 tentang Pemungutan dan Penghitungan Suara dalam Pemilihan Umum Pasal 8 ayat 5 sampai 15 . Hal yang sangat baik ketika pemerintah memberikan kesempatan pemilih menggunakan form A5-KPU apabila tidak dapat memilih di TPS daerah ia tinggal. Secara yuridis aturan tersebut telah jelas mengatur, dan melindungi hak pilih warga Negara, namun sayangnya hal tersebut belum bisa mengakomodir kebutuhan masyarakat sehingga tidak dapat berjalan sesuai dengan yang diinginkan karena terbentur dengan prosedur pelaksanaan, pengaruh kesadaran masyarakat, serta edukasi pelayanan dari sektor PPS kepada KPPS. Untuk itu perlu adanya formulasi ulang aturan tersebut untuk bisa melindungi secara menyeluruh hak-hak setiap warga Negara untuk tetap bisa memberikan hak pilihnya. Negara dalam hal ini tugasnya dilaksanakan oleh KPU telah berupaya untuk memfasilitasi agar seluruh masyarakat Indonesia ikut berpartisipasi dalam pemilihan umum, mengingat setiap suara pemilih dalam pemilu sangat menentukan masa depan bangsa sebab pemilu di Indonesia sebagai manifestasi dari demokrasi, diharapkan mendatang terdapat peraturan pemilu yang menjawabnya.

\section{Saran}

Kepada Komisi Pemulihan Umum seharusnya lebih bisa melindungi haknya terkait peraturan agar lebih responsif terhadap permasalahan yang dimungkinkan dapat terjadi dalam proses pemilihan umum. Peristiwa dan kaitan-kaitannya terhadap orang-orang yang ada dalam situasi tertentu dan mendeskripsikan fakta sebagaimana adanya (fenomonologi). Penggalian makna dan nilai dari masyarakat seharusnya menjadi basis penegakan hukum yang penuh kearifan lokal sejalan dengan kondisi masyarakat Indonesia yang beragam. 


\section{Daftar Pustaka}

Buku

Boer Mauna, Hukum Internasional, Pengertian, Peranan dan Fungsi dalam Era Dinamika Global, Alumni, Bandung, 2003.

Komisi Pemilihan Umum Republik Indonesia, Panduan Pelaksanaan Pemungutan dan Penghitungan Suara di TPS Pemilu Tahun 2019.

Moh. Mahfud MD, Politik Hukum di Indonesia, Rajawali Pers, Jakarta, 2017.

Peter Mahmud Marzuki, Penelitian Hukum, (edisi revisi), Prenadamedia Group, Jakarta, 2015.

Soetandyo Wignjosoebroto, Hukum: Konsep dan MetodeSetara Press, Malang, 2013.

Jurnal

Agus Machfud Fauzi, Perilaku Pemilih Menjelang Pemilu 2019, Journal of Islamic Civilization, 1.1, 2019.

Andi Yuliani, Hak Konstitusional Warga Negara, Artikel Hukum Tata Negara dan Peraturan Perundang-undangan, diakses dari http: //ditjenpp.kemenkumham.go.id/htn-dan-puu/2971-hakkonstitusional-warga-negara.html Pada 22 September 2019.

Andi Yuliani, Hak Politik Warga Negara (Sebuah Perbandingan Konstitusi), Artikel Hukum Tata Negara dan Peraturan Perundang-Undangan, diakses dari http://ditjenpp.kemenkumham.go.id/htn-dan-puu/2941-hak-politikwarga-negara-sebuah-perbandingan-konstitusi.html pada 23 September 2019.

Ayon Diniyanto, Politik Hukum Regulasi Pemilihan Umum di Indonesia: Problem dan Tantangannya, Jurnal Legislasi Indonesia, 16.2, (2019).

Bobi Aswandi dan Kholis Roisah, Negara Hukum dan Demokrasi Pancasila dalam Kaitannnya dengan Hak Asasi Manusia (HAM), Jurnal Pembangunan Hukum Indonesia, 1.1, (2019).

Cora Elly Noviati, Demokrasi dan Sistem Pemerintahan, Jurnal Konstitusi, 10.2, (2013).

Ester Meita Motoh, Kinerja Komisi Pemilihan Umum Minahasa Selatan dalam Pelaksanaan Pemilu Legislatif Tahun 2014, Jurnal Politico, 7.3, (2018).

Lati Praja Delmana, Aidinil Zetra, dan Alfan Miko, Konstruksi Indikator dan Formula Penilaian Kualitas Pemilihan Umum di Indonesia, JPPUMA: Jurnal Ilmu Pemerintahan dan Sosial Politik UMA, 7.1, 2019.

Nopi Amalia dan Andi Mulyadi, Strategi Komisi Pemilihan Umum dala Mengurangi Angka Golput Pada Pemilihan Presiden dan Wakil Presiden, JOPPAS: Journal of Public Policy and Administration Silampari, 1.1, 2019. 
R. Siti Zuhro, Demokrasi dan Pemilu Presiden 2019, Jurnal Penelitian Politik LIPI dalam Dinamika Sosial Politik Menjelang Pemilu Serentak 2019, 16.1, 2019.

Internet

"Mahasiswa Tak Bisa Mengurus Formulir A5, Kenapa?", https://www.idntimes.com/news/indonesia/sunariyah/mahasiswatak-bisa-mengurus-formulir-a5-kenapa, diakses tanggal 21 September 2019.

\section{Peraturan Perundang-Undangan}

UU No.7 Tahun 2017 tentang Pemilihan Umum, Berita Negara Republik Indonesia Tahun 2017 Nomor 1225

PKPU Nomor 7 tahun 2019 tentang Perubahan Ke Tiga atas PKPU Nomor 7 tahun 2019 tentang Tahapan, Program, dan Jadwal Penyelenggaraan Pemilihan Umum tahun 2019, Berita Negara Republik Indonesia Tahun 2019 Nomor 277

Peraturan Komisi Pemilihan Umum (PKPU) Nomor. 3 Tahun 2019 Tentang Pemungutan dan Penghitungan Suara dalam Pemilihan Umum, Berita Negara Republik Indonesia Tahun 2019 Nomor 83.

\section{Wawancara}

Wawancara dengan Noor Kholifah Hidayati Mahasiswi Magister Ilmu Hukum Universitas Diponegoro angkatan 2019, asal Semarang, pada 25 November 2019. 